\title{
Optimal stocking density for Nile tilapia, Orechromis niloticus within biofloc system
}

\author{
Osama M. El-Husseiny ${ }^{1}$, Ashraf M. A-S. Goda ${ }^{2}$, Rania S. Mabroke ${ }^{1}$, Mohamed Souady ${ }^{2}$ \\ ${ }^{1}$ Animal production department, Faculty of agriculture, Cairo University, Egypt \\ ${ }^{2}$ Fish Nutrition Laboratory, National Institute of Oceanography and Fisheries (NIOF), Cairo, Egypt
}

\begin{abstract}
Considering limit water sources for aquaculture in Egypt, biofloc system is one of the answers. Biofloc system limits water exchange during the aquaculture process. Successful application in tilapia culture was our concern. Therefore, the experiment was established to detect the optimal fish density within biofloc system. Three stocking density $\left(100,150,200 \mathrm{fish} / \mathrm{m}^{3}\right)$ were examined for the optimal density within biofloc system. Fish with average weight of $(6.08 \pm 0.22)$ were randomly distributed in to plastic tanks of $150 \mathrm{~L}$ water capacity in triplicate each to examine the different density on tilapia growth performance, feed utilization, water quality parameters, and water count of zooplankton. The best growth performance and feed utilization were recorded for100 fish $/ \mathrm{m}^{3}$ (D1). With the increase of stocking density, a depression in growth performance was recognized. All water quality parameters (total ammonia nitrogen, $\mathrm{No}_{2}, \mathrm{pH}$ and temperature) ranged around safe values except for $\mathrm{NO}_{3}$. The highest water total zooplankton counts were recorded for (D1). The present results indicate that the optimal stocking density for Nile tilapia within biofloc system was $100 \mathrm{fish} / \mathrm{m}^{3}$.
\end{abstract}

Key words: biofloc, stocking density, Nile tilapia

\section{Introduction}

Biofloc is a new system, which offers a solution to some problems of aquaculture industry. These problems are a shortage of dietary protein resources, shortage of water supply and environmental impacts (Timmons \& Ebling, 2007). Biofloc system definition is aquaculture without water exchange, under high stocking density, or development and control of dense heterotrophic microbial flocs in the water column by adding carbon source to fish culture pond. It combines the removal of nutrient (ammonia) from the water by encourage the growth of heterotrophic bacteria, which utilize ammonia for growth. Controlling the water ammonia level lead to the possibility to decrease fish pond water discharge even zero water exchange could be reached (De Schryver et al., 2008).

Few studies discussed the nutrient requirement and optimal fish density under the biofloc system. Density may impair the growth and reduce immune competence due to clustering stress and the deterioration of water quality. These factors can affect either the feed intake or conversion efficiency of the fish (Ellis et al., 2002). Previous studies have demonstrated that the stocking density can affect fish growth performance even though water quality in aquaculture systems was kept in good conditions (Tolussi etal., 2010). Ayyat et al., (2011) and AbdelTawwab (2012) reported that fish growth was inversely affected by rearing density and the optimal density resulted in the best growth performance was $150 \mathrm{fish} / \mathrm{m}^{3}$. Ridha (2006) reported that density of $200 \mathrm{fish} / \mathrm{m}^{3}$ significantly decreased the growth performance of Nile tilapia compared with a density of $125 \mathrm{fish} / \mathrm{m}^{3}$. Therefore, this study was designed to detect the optimal stocking density within biofloc system, where fish fed on dietary protein $(30 \%)$ with in biofloc conditions.

\section{Materials and Methods}

\section{Experimental fish \& Culture techniques}

The study was conducted in the experimental fish farm, El-Kanater El-Khayria, National Institute of Oceanography and Fisheries (NIOF), Delta Barrage, Kalubiya Governorate, Egypt, to investigate the optimal fish density for Nile tilapia within biofloc system. Three stocking density 100 (D1), 150 (D2) and 200 (D3) (fish/ $\mathrm{m}^{3}$ ) was examined for thesis effect on tilapia performance, water quality and zooplankton counts. Tilapia was obtained from the El-Kanater El-Khayria, Kalubiya Governorate, Egypt. Fish was acclimatized to laboratory condition for two weeks. Tilapia fingerlings were stocked into nine cylindrical plastic tank (with water capacity of 100L each) at a rate of 100 (D1), 150 (D2) and 200 (D3) fish $\operatorname{tank}^{-1}$, representing the three experimental treatments in triplicate each. The tanks were supplied with well water source. Aeration was continuously provided using an air blower. Fish were held under natural light (12:12 h, light: dark schedule) and all experimental tanks were always covered with black plastic sheets. Water in the experimental tanks has never exchanged during the experimental period (75 days) except the evaporation compensate. Fish was fed on a single diet ( $30 \%$ protein) Table 1 . The daily ration was $3 \%$ of the total stocking biomass divided into two equal amounts and offered twice daily (9.00 and $14.00 \mathrm{~h}$ ). Fish in each replicate aquaria was weighed every 15 days and the amount of the daily allowance feed was accordingly adjusted. 
Starch was added for all treatments at the same amount of feeding ration to maintain the optimal C: $\mathrm{N}$ ratio for activate heterotrophic bacteria growth (>N10:1) (Avnimelech, 1999). Starch was completely mixed in a beaker with tank water sample and spread over the tank surfaces in the afternoon time. Adding carbohydrate, shading tanks and aeration condition are the main circumstances that cause floc growth and development (Azim and Little, 2008).

Table 1. Formulation and chemical composition of the experimental diet

\begin{tabular}{lc}
\hline Ingredients & $30 \%$ \\
\hline Soya bean meal & 65 \\
Yellow corn & 13 \\
Wheat bran & 14 \\
Soya oil & 6 \\
Vit. and Min. premix ${ }^{1}$ & 1.45 \\
CMC $^{2}$ & 0.5 \\
Vit. C & 0.05 \\
Dry matter $(\%)$ & 91.10 \\
Protein $(\%)$ & 30.95 \\
Lipid \% & 11.28 \\
Total carbohydrate $(\%)^{3}$ & 41.44 \\
Ash \% & 7.43 \\
Gross energy $(\mathrm{kJ} / \mathrm{kg})^{4}$ & 1888.75 \\
Metabolizable energy $(\mathrm{kJ} / \mathrm{kg})$ & 1322.13 \\
\hline
\end{tabular}

(1)Vitamins and minerals mixture each $3 \mathrm{Kg}$ of mixture content: $12 \mathrm{~m} . \mathrm{IU}$ vit $\mathrm{A}, 22 \mathrm{mIUvit} \mathrm{D} 3,10 \mathrm{~g}$ vit $\mathrm{E}, 2 \mathrm{~g}$ vit $\mathrm{K}, 1 \mathrm{~g}$ vit. B1, $5 \mathrm{~g}$ vit. B2, 1.5g vit. B6,10 mg.vit.B12, 30g.niacin, 1000mg.Folic acid,50mg.Biotin, 10g banathonic acid, 50g Zinc ,30g. Iron , 60g.Manganese, 4g Copper , 100mg.Coblat, 100mg Selenium , 1000mg iodine.

${ }^{2} \mathrm{CMC}$ : Carboxy methyl cellulose

${ }^{3}$ Total carbohydrate $=100-(\mathrm{CP}+\mathrm{EE}+\mathrm{Ash})$

${ }^{4}$ Calculated using gross calorific values of $23.63,39.52$ and $17.15 \mathrm{Kcal} \mathrm{g}^{-1}$ for protein, fat and carbohydrate, respectively according to Brett (1971).

\section{Experimental Diets}

Experimental diets were processed by blending the dry ingredients into a homogenous mixture. The mixture feed was passed through a laboratory pellet mill at the National Institute of Oceanography and Fisheries, Cairo Governorate, Egypt (California Pellet Mill, San Francisco, CA, USA). The experimental diets were solar dried and storied at -4 $\mathrm{C}^{\circ}$. Dietary gross energy (GE) contents were calculated according to gross caloric values of Brett (1971) using the values of 23.6, 39.5, and $17.2 \mathrm{~kJ} \mathrm{~g}^{-1}$ for crude protein, crude fat, and total carbohydrate, respectively. The metabolizable energy (ME) was estimated by applying the coefficient of $70 \%$ from determined GE values according to Hepher et al., (1983).

\section{Growth indices}

Mean final body weight (FBW) of each experimental treatment was determined by dividing total fish weight in each tank by number of fish. Weight gain (WG), specific growth rate (SGR \%), feed conversion ratio (FCR), protein efficiency ratio (PER), protein productive value (PPV), energy retention (ER) were calculated using the following equations:

$\mathrm{WG}=$ Final body weight $(\mathrm{g})$ - Initial body weight $(\mathrm{g})$
$\mathrm{SGR} \%=(\ln \mathrm{FBW}-\ln \mathrm{IBW}) / \mathrm{t} \times 100$; where: FBW is final body weight $(\mathrm{g})$; IBW is initial body weight $(\mathrm{g})$; $\mathrm{ln}=$ natural logarithmic; $\mathrm{t}=$ time in days

FCR $=$ diet intake $(\mathrm{g})$ /weight gain $(\mathrm{g})$

PER = weight gain $(\mathrm{g}) /$ protein intake $(\mathrm{g})$

PPV\% $=($ protein gain $(\mathrm{g}) /$ protein intake $(\mathrm{g})) \times 100$

$\mathrm{ER} \%=($ energy gain $(\mathrm{kJ}) /$ energy intake $(\mathrm{kJ})) \times 100$.

\section{Chemical Analysis.}

A random pooled sample of fish was collected at the beginning and the end of the trial and sacrificed for determination of initial whole-body proximate composition. Fish samples were oven-dried, ground, and stored at $-20^{\circ} \mathrm{C}$ for subsequent analysis. The chemical composition of fish and diet samples were determined according to the procedures of AOAC (1995). Dry matter was determined after drying the samples in an oven $\left(105^{\circ} \mathrm{C}\right)$ for $24 \mathrm{~h}$. Ash by incineration at $550^{\circ} \mathrm{C}$ for $12 \mathrm{~h}$. Crude protein was determined by micro-Kjeldhal method, $\% \mathrm{~N} \times 6.25$ (using Kjeltech autoanalyzer, Model 1030, Tecator, Höganäs, Sweden) and crude fat by Soxhlet extraction with diethyl ether $\left(40-60^{\circ} \mathrm{C}\right)$.

\section{Water quality.}

Water $\mathrm{pH}$ and temperature was recorded twice weekly at $13.00 \mathrm{~h}$ using a mercury thermometer suspended at $30-\mathrm{cm}$ depth. Water samples $(50 \mathrm{ml})$ 
were collected fortnightly from each tank and filtered by filter papers. Ammonia, nitrite and nitrate were determined every 15 days. Calorimetrically measurement of different water parameters was done using Spectrophotometer model (LKB Bichrom UV visible spectrophotometer) according to APHA, (1992) and Mullin and Riley (1955).

\section{Taxonomic composition and total count of zooplankton}

Zooplankton was collected from experimental tanks, 10 liters of every water sample were filtered through plankton net $55 \mu$ mesh size, $25 \mathrm{~cm}$ diameter and $80 \mathrm{~cm}$ length. Each collected sample was transferred to a labeled clean bottle and immediately fixed with $4 \%$ formaldehyde.

Three sub-samples (one $\mathrm{ml}$ for each) of the homogenized plankton samples were transferred into a counting cell and zooplankton species were identified. The sub-samples were examined under a binocular research microscope with magnification varied from $100 \mathrm{X}$ to $400 \mathrm{X}$. Zooplankton population density was then calculated as the number of individuals per cubic meter from the equation conducted by (APHA, 1995):

No. $X \mathrm{~m}^{-3}=\left(\mathrm{c} \mathrm{X} \mathrm{v}^{\prime}\right) /\left(\mathrm{v}^{\prime \prime} \mathrm{x} \mathrm{v^{ \prime \prime \prime }}\right) \times 1000$

Where:-

$\mathrm{c}=$ number of organisms counted.

$\mathrm{v}^{\prime}=$ volume of concentrated sample, $\mathrm{ml}$.

$\mathrm{v}^{\prime \prime}=$ volume counted, $\mathrm{ml}$

$\mathrm{v}^{\prime \prime \prime}=$ volume of the grab sample, liters.
Zooplankton species were identified according to Edmondson (1963); Ruttner-Kolisko (1971); Pennak (1978); Pontin (1978); Wallace and Snell (1991); Foissner and Berger (1996).

\section{Statistical analysis}

All variables measured at harvest (fish growth, yield, FCR, SGR and PER,) and various components in the nitrogen budgets were analyzed by 1 -way ANOVA was carried out to determine the effect of stocking rate. All the ANOVA were performed using the SAS v9.0.0 program . The ANOVA was followed by Duncan test at $\mathrm{P} \leq 0.05$ level of significant.

\section{Results and Discussions}

Growth performance and feed utilization parameters of Nile tilapia in different treatments with stocking density of 100, 150 and $200 \mathrm{fish} / \mathrm{m}^{3}$ (D1, D2 and $\mathrm{D} 3$, respectively) within biofloc system are presented in Tables 2 and 3. Significant differences in tilapia growth performance between stocking densities was recognized. The highest final body weight, the highest weight gain and specific growth rate were recorded for stocking density100 fish $/ \mathrm{m}^{3}$ (D1). Meanwhile, increasing stocking density, depressed feed utilization. High stocking density might inhibit fish growth through decreasing food conversion efficiency. High stocking density of Amur sturgeon (Acipensers chrenckii) has negative effects on growth, where significant decrease in specific growth rate was observed when stocking density was increased (Li et al., 2012).

Table 2. Effect of stocking density on tilapia growth within biofloc system

\begin{tabular}{lcccc}
\hline Stocking density & IB W & FBW & WG & SGR \\
\hline $100 \mathrm{Fish} / \mathrm{m}^{3}$ & 6.34 & $20.01^{\mathrm{a}}$ & $13.66^{\mathrm{a}}$ & $1.35^{\mathrm{a}}$ \\
$150 \mathrm{Fish} / \mathrm{m}^{3}$ & 6.11 & $15.98^{\mathrm{b}}$ & $9.87^{\mathrm{b}}$ & $1.28^{\mathrm{b}}$ \\
$200 \mathrm{Fish} / \mathrm{m}^{3}$ & 5.80 & $13.25^{\mathrm{c}}$ & $7.45^{\mathrm{c}}$ & $1.10^{\mathrm{c}}$ \\
SE & 0.22 & 0.38 & 0.06 & 0.01 \\
\hline
\end{tabular}

* Data are presented as means \pm standard error (SE).

** Means followed by different letters in each column are significantly $(\mathrm{P}<0.05)$ different

Table 3. Effect of stocking density on tilapia feed utilization within biofloc system

\begin{tabular}{lccccc}
\hline Stocking density & FI $(\mathbf{g})$ & FCR(g) & PER(g) & PPV(g) & ER \\
\hline $100 \mathrm{Fish} / \mathrm{m}^{3}$ & $21.45^{\mathrm{a}}$ & $1.57^{\mathrm{c}}$ & $1.89^{\mathrm{a}}$ & $25.89^{\mathrm{a}}$ & $35.09^{\mathrm{a}}$ \\
$150 \mathrm{Fish} / \mathrm{m}^{3}$ & $18.54^{\mathrm{b}}$ & $1.88^{\mathrm{b}}$ & $1.72^{\mathrm{b}}$ & $19.91^{\mathrm{b}}$ & $34.97^{\mathrm{a}}$ \\
$200 \mathrm{Fish} / \mathrm{m}^{3}$ & $16.76^{\mathrm{c}}$ & $2.25^{\mathrm{a}}$ & $1.44^{\mathrm{c}}$ & $14.51^{\mathrm{c}}$ & $24.63^{\mathrm{b}}$ \\
$\mathrm{SE}$ & 0.11 & 0.02 & 0.01 & 0.13 & 0.18 \\
\hline
\end{tabular}

* Data are presented as means \pm standard error (SE).

** Means followed by different letters in each column are significantly $(\mathrm{P}<0.05)$ different

A stocking density of $100 \mathrm{fish} / \mathrm{m} 3$ produced the best growth performance for tilapia fish. Increase of stocking density inversely affected the growth of Nile tilapia compared with low stocking density where, final body weight and daily weight gain were significantly $(\mathrm{P}<0.001)$ higher at lower stocking density. Abdel-Tawwab (2012) reported that fish growth was inversely affected by rearing density, density of $150 \mathrm{fish} / \mathrm{m}^{3}$ produced the best growth performance. The Same trend for Nile tilapia was shown by Ayyat et al., (2011). A density of 200 $\mathrm{fish} / \mathrm{m}^{3}$ significantly decreased the growth 
performance of Nile tilapia compared with a density of $125 \mathrm{fish} / \mathrm{m}^{3}$ (Ridha 2006). The phenomena was analyzed in many cultivated fish species, inverse relation between growth and feed rearing density, is mainly attributed to social interactions such as competition for food and/or space that can negatively affect fish growth (Canario et al., 1998 and Irwin et al., 1999). High stocking density is attributed to an alteration in metabolism due to physiological stress. In addition, high stocking density may elevate a cortisol level ( Lupatsch et al., 2010). Cortisol is commonly accepted being indicative of stress, which cause increased basic metabolic rate and mobilization of energy reserve. In case of stress, the energy required for growth is deviated to supply the increase in metabolic rate, which may lead to a drop in food conversion efficiency (Tolussi et al., 2010). Another reason may cause growth inhibition and feed utilization of fish under high density is high levels of locomotory activity and elevated metabolic rates measured in rainbow trout (Cooke etal., 2000) . Fish density can affect the efficiency of feed utilization; as long as the number of fish stocked in pond increases, the amount of feed available to each fish decreases (Chang 1988).

The proximate whole body analysis of tilapia is summarized in Table 4. Tilapia protein and ash contents increased with decreasing fish density. Dry matter and lipids, decreased with density elevated. The low lipid content of high-density-reared fish finds confirmation with Montero et al., (1999) who found that lower lipid levels in the liver of gilthead sea bream, Sparus aurata, reared at high densities. Furthermore, Piccolo et al., (2008) evaluated the effect of feed quality and stocking density on Dover sole, Solea solea detected higer lipid content in the low-density group, proximate composition of the sole's muscle was not influenced by treatments. Abdel-Tawwab et al., (2006) reported that the changes in protein and lipid contents in the fish body could be associated with changes in their synthesis and/or deposition rate in the muscles.

Table 4. Effect of stocking on tilapia body composition within biofloc system

\begin{tabular}{lcccc}
\hline Stocking density & Dry mater & Ash & Protein & Fat \\
\hline $100 \mathrm{Fish} / \mathrm{m}^{3}$ & $25.44^{\mathrm{a}}$ & $15.86^{\mathrm{b}}$ & $57.96^{\mathrm{b}}$ & $21.58^{\mathrm{a}}$ \\
$150 \mathrm{Fish} / \mathrm{m}^{3}$ & $25.48^{\mathrm{a}}$ & $17.32^{\mathrm{a}}$ & $57.84^{\mathrm{b}}$ & $20.74^{\mathrm{a}}$ \\
$200 \mathrm{Fish} / \mathrm{m}^{3}$ & $24.20^{\mathrm{b}}$ & $17.79^{\mathrm{a}}$ & $60.40^{\mathrm{a}}$ & $16.99^{\mathrm{b}}$ \\
$\mathrm{SE}$ & 0.27 & 0.38 & 0.79 & 0.59
\end{tabular}

* Data are presented as means \pm standard error (SE).

** Means followed by different letters in each column are significantly $(\mathrm{P}<0.05)$ different

During the experimental period, water temperature ranged 26-30 while, $\mathrm{pH}$ was $6.0-8.5$. Total ammonia nitrogen (TAN) values were in the safely range $(0.5-2 \mathrm{mg} / \mathrm{L})$ (Fig. 1). $\mathrm{NO}_{2}$ figured around the normal range $(0.5 \mathrm{mg} / \mathrm{L})$ (Fig.2). Nitrate recorded higher values than a normal range $(5 \mathrm{mg} / \mathrm{L})$ for all experimental treatments (Fig. 3). Density did not affect water quality parameters within biofloc system. It was suggested that fish had no effect on water quality parameters ( $\mathrm{Li}$ et al., 2012). Water quality kept at the same level for low, medium, and high stocking densities (initial experimental densities were $0.30,0.75$, and $1.78 \mathrm{~kg} \mathrm{~m}-2$, respectively). Neverless, Abdel-Tawwab (2012) reported that, unionized ammonia (UA) was significantly affected by rearing density. Ayyat et al., (2011) suggested that the fish stocking density were significantly affected the concentrations of dissolved oxygen and $\mathrm{pH}$, and decreased with increasing fish density, while the concentrations of ammonia, nitrite, and nitrate increased.

Zooplankton species and counts of different experimental treatments are presented in Table 5. Highest total count of zooplankton was recorded for
$\left(\mathrm{D} 1 ; 100 / \mathrm{m}^{3}\right)$. The increase of stocking density decreased the total count of zooplankton. Low density fish consumed much feed and elevated the fish output (feces). In the presence of starch, a suitable environment for microorganisms (biofloc) and zooplankton, growth established. Meanwhile, active growth of biofloc within this condition exceeded the fish ability of consuming. Crab et al., (2007) conclude that the biological flocs can be considered a kind of fast growing microbial mixed culture in which the 'waste'-nitrogen is recycled to young cells, which subsequently are grazed by the fish. 


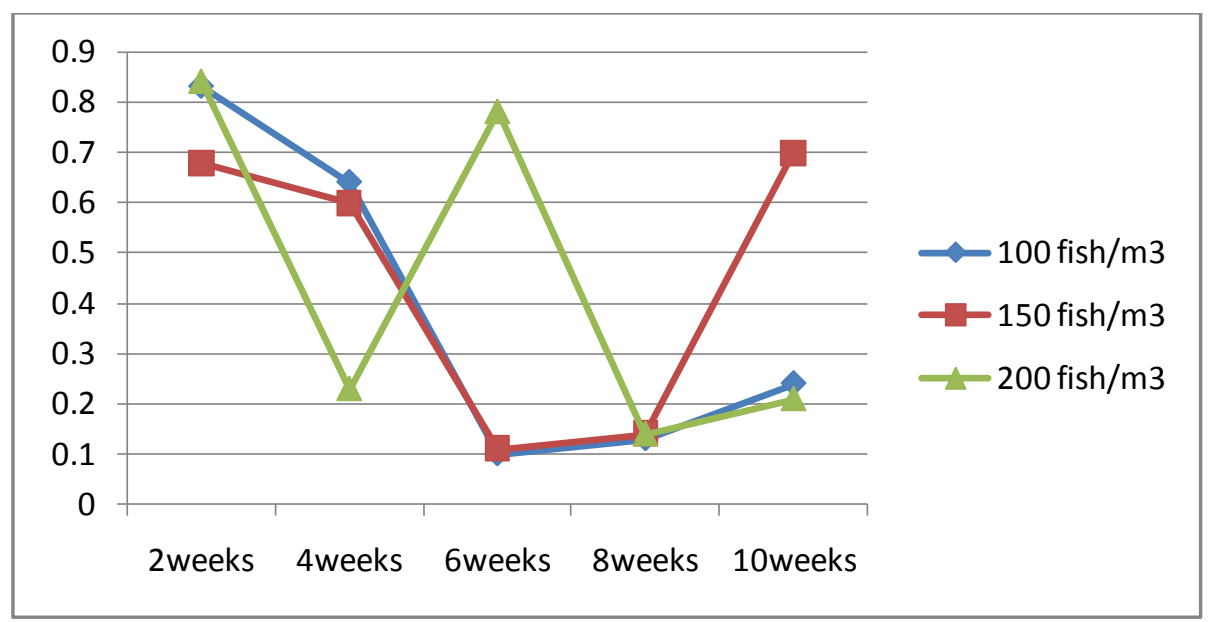

Fig. 1.Total ammonia nitrogen of experimental treatments with different socking density within biofloc system.

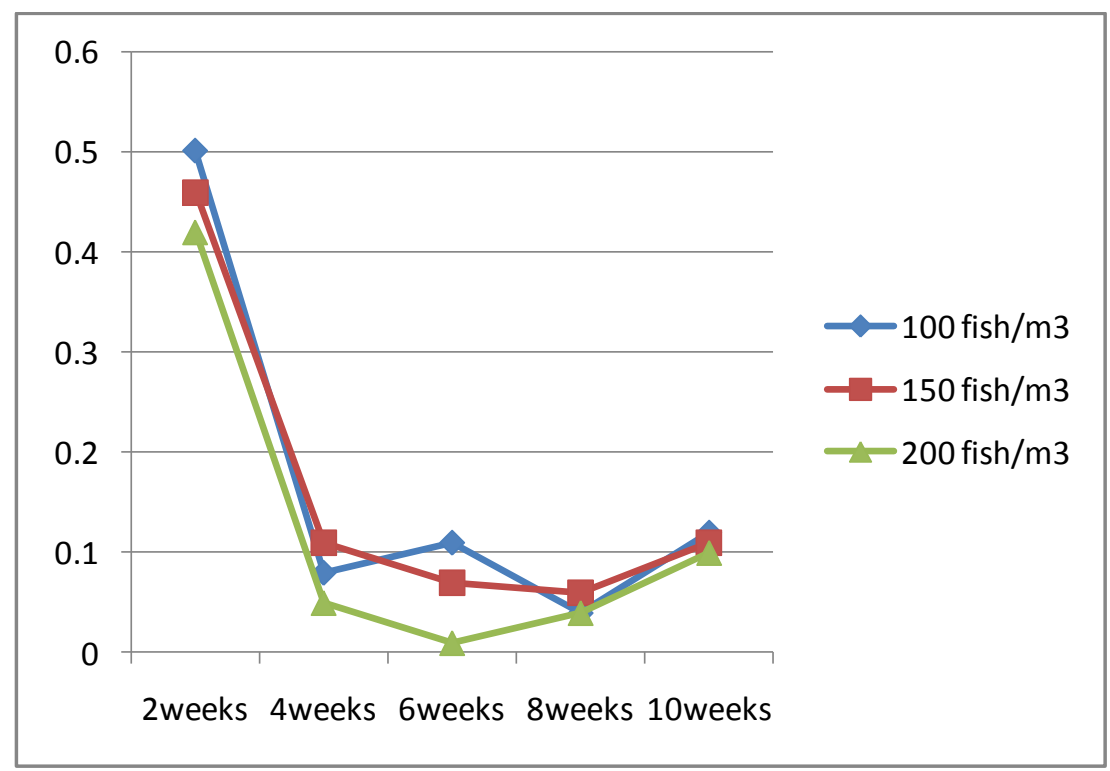

Fig. 2. Nitrite of experimental treatments with different socking density withhin biofloc system. 


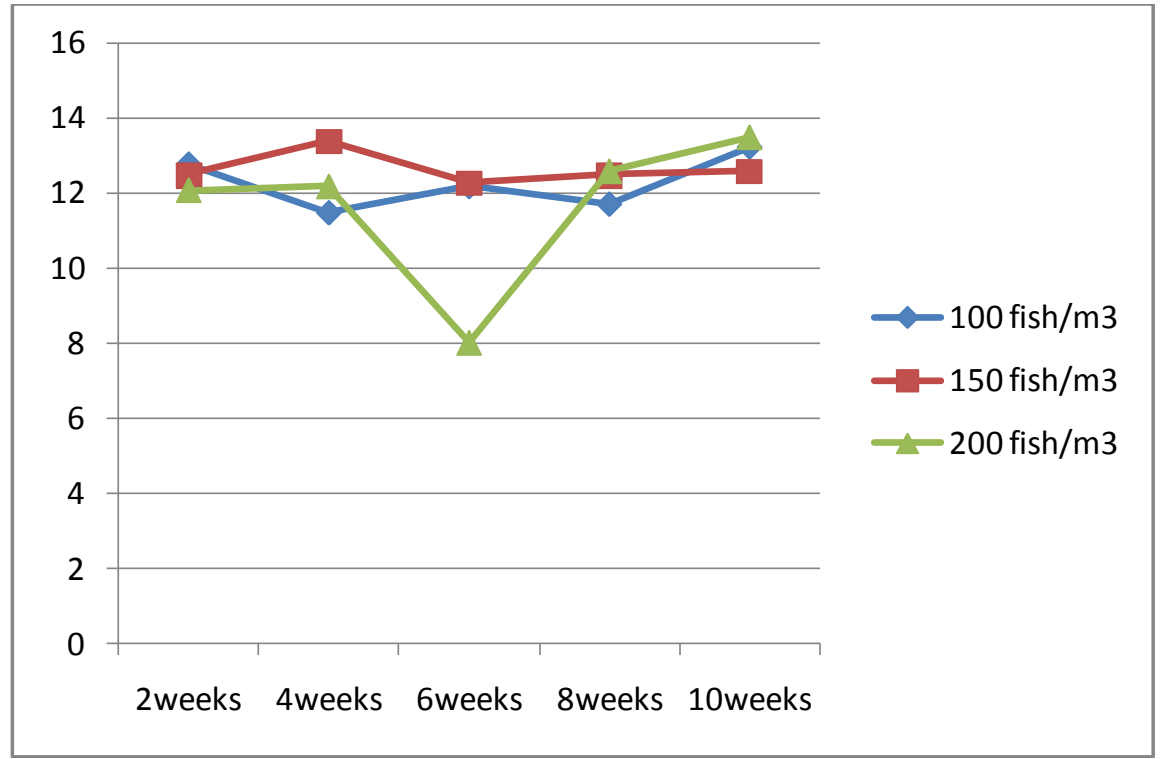

Fig. 3. Nitrate of experimental treatments with different socking density within biofloc system.

Table 5. Effect of stocking density of zooplankton counts within biofloc system

\begin{tabular}{|c|c|c|c|c|}
\hline Groups & Types of zooplankton & $100 \mathrm{Fish} / \mathrm{m}^{3}$ & $150 \mathrm{Fish} / \mathrm{m}^{3}$ & $200 \mathrm{~F}$ ish $/ \mathrm{m}^{3}$ \\
\hline \multirow{8}{*}{ Rotifera } & Lepadellaovalis (O. F. Muller) & 81667 & 0 & 0 \\
\hline & $\begin{array}{l}\text { Monostyllaclosterocerca } \\
\text { (Schmarda) }\end{array}$ & 425333 & 75333 & 43333 \\
\hline & Philodenasp & 13500 & 3000 & 0 \\
\hline & Collothecasp & 74000 & 47667 & 41667 \\
\hline & Anuraeopsisfissa (Gosse) & 3333 & 0 & 0 \\
\hline & Anuraeopsisfissa (Gosse) & 3333 & 0 & 0 \\
\hline & Colurellaadriatica (Ehrenberg) & 133000 & 22333 & 56500 \\
\hline & $\begin{array}{l}\text { Euchlanissp } \\
\text { Tokophyraquadripartita (Goodrich }\end{array}$ & 0 & 8333 & 0 \\
\hline \multirow{3}{*}{ Protozoa } & \&Jahn) & 143667 & 68667 & 0 \\
\hline & Vorticella campanula (Ehrenberg) & 234333 & 76000 & 59000 \\
\hline & Arcella vulgaris (Ehrenberg) & 64667 & 2333 & 0 \\
\hline Copepoda & copepotidae & 0 & 0 & 5000 \\
\hline Total coun & ancton & 1176833 & 303666 & 205500 \\
\hline
\end{tabular}

* Data are presented as means \pm standard error (SE).

** Means followed by different letters in each column are significantly $(\mathrm{P}<0.05)$ different. 


\section{Conclusion}

Expanding of biofloc system in aquaculture industry, future work is needed for detecting the nutrient and management requirement within biofloc conditions. Stocking density of $100 \mathrm{fish} / \mathrm{m}^{3}$ (D1) under BFT noticed for the best fish performance, feed utilization, water quality and the total count of zooplankton.

\section{References}

Abdel-Tawwab, M. (2012). Effects of dietary protein levels and rearing density on growth performance and stress response of Nile tilapia, oreochromis niloticus (L.) International Aquatic Research, 4:3:1-13.

Abdel-Tawwab, M.; Y.A.E. Khattab; M.H. Ahmad and A.M.E. Shalaby (2006). Compensatory growth, feed utilization, whole body composition and hematological changes in starved juvenile Nile tilapia, Oreochromis niloticus (L.). J Appl Aquacult, 18:17-36.

Avnimelech, Y. (1999). Carbon/nitrogen ratio as a control element in aquaculture systems. Aquaculture, 176:227-235.

A.O.A.C. (1995). Official methods of analysis, 15th ed. Association of Official Analytical Chemists, Arlington, VA.

A.P.H.A. (1992). Standard Methods for the examination of water and waste water, 18th ed. American Public Health Association, Washington DC. 1268.

A.P.H.A. (1995). Standard methods for the examination of water and waste water (19111 ed.). American Public Health Association, Washington, DC. 1082 pp.

Ayyat M.S.; H.I. El-Marakby and S.M. Sharaf (2011). Effect of dietary protein level, stocking density, and dietary pantothenic acid supplementation rate on performance and blood components of Nile tilapia Oreochromis niloticus. J Appl Aquacult, 23:122-135.

Azim, M.E. and D.C. Little (2008). The bio- floc technology (BFT) in indoor tanks: Water quality, bio -floc composition, and growth and welfare of Nile tilapia (Oreochromis niloticus) Aquaculture, 283: 29-35.

Brett, J. R., (1971). Energetic responses of salmon to temperature. A study of some thermal relations in the physiology and fresh water ecology of sockeye salmon (Oncrhynchus nerka). American zoologist 11: 99-113.

Canario A.V.M.; J. Condeça ; D.M. Power and P.M. Ingleton (1998). The effect of stocking density on growth in gilthead seabream, Sparus aurata (L.). Aquacult Res, 29:177-181.

Chang W.Y.B. (1988). Fish production: data synthesis and model development. In: Pond dynamics/aquaculture Collaborative Research Support Program (CRSP), 6th annual administrative report. Oregon State University, Oregon, 41-49.

Cooke S.J.; K.P. Chandroo; T.A. Beddow; R.D. Moccia and R.S. McKinley (2000). Swimming activity and energetic expenditure of captive rainbow trout Oncorhynchus mykiss estimated by electromyogram telemetry. Aquacult Res, 31:495-505.

Crab, R.; Y. Avnimelech ; T. Defoirdt ; P. Bossier and W. Verstraete (2007). Nitrogen removal techniques in aquaculture for a sustainable production. Aquaculture, 270: 1-14.

De Schryver, P.; R. Crab ; T. Defoirdt ; N. Boon and W. Verstraete (2008). The basics of bioflocs technology: The added value for aquaculture. Aquaculture, 277:125-137.

Edmondson, W.T. (1963). Fresh water biology. 2nd ed. John Wiley and Sons. Inc., New York \& London. 1248.

Ellis, T.; B. North ; A.P. Scott ; N.R. Bromage ; M. Porter and D. Gadd (2002). The relationships between stocking density and welfare in farmed rainbow trout. J Fish Biol 61:493-531.

Foissner, W. and H. Berger (1996). A user-friendly guide to the ciliates (Protozoa, Ciliophora) commonly used by ydrobiologists as bioindicators in rivers, lakes and waste waters with notes on their ecology. Freshwater Biol., 35: $375-482$.

Hepher, B.; I.C. Liao ; S.H. Cheng and C.S. Haseih (1983). Food utilization by red tilapia. Effect of diet composition, feeding level and temperature on utilization efficiency for maintenance and growth. Aquaculture, 32: 255 -272 .

Huang W.B. and T.S. Chiu (1997). Effects of stocking density on survival, growth, size variation, and production of Tilapia fry. Aquacult Res 28:165-173 intensive aquaculture systems with a limited water exchange and adjusted carbon to nitrogen ratio. Israeli Journal of Aquaculture - Bamidgeh, 46 (3): 119-131.

Irwin S.; J.O. Halloran and R.D. FitzGerald (1999). Stocking density, growth and growth variation in juvenile turbot, Scophthalmus maximus (Rafinesque). Aquaculture 178:77-88

Li, D.; Z. Liu and C. Xie (2012). Effect of stockng density on growth and serum oncentratons of thyroid hormons and cortsol in Amur sturgeon (Acipenserschrenckii).Fish physiology biochmestiry 38:511-520.

Lupatsch I.; G.A. Santos ; J.W. Schrama and J.A.J. Verreth (2010). Effect of stocking density and feeding level on energy expenditure and stress responsiveness in European sea bass Dicentrarchus labrax. Aquaculture, 298:245250.

Montero D.; M.S. Izquierdo; L. Tort; L. Robaina and J.M. Vergara (1999). High stocking density produces crowding stress altering some 
physiological and biochemical parameters in gilthead seabream, Sparus aurata, juveniles. Fish Physiol Biochem 20:53-60.

Mullin, J. B. and J. P. Riley (1955). The colorimetric determination of silicate with reference to sea and natural waters. Anal. Chim. Acta, 12, 162-176.

Pennek, W. R. (1978). Freshwater investigation of the United States: 803 pp. 2nd Edition, John Wiley and Sons, New York., USA.

Piccolo, G.; S. Marono,; F. Bovera ; R. Tudisco; G. Caricato and A. Nizza (2008). Effect of stocking density and protein/fat ratio of the diet on the growth of Dover sole (Solea solea). Aquacult Res, 39:1697-1704.

Pontin, R. M. (1978). A key to the freshwater planktonic and semi-planktonic Rotifera of the British Isles, 178 pp. Freshwater Biological Association, Scientific Publication 38.

Ridha, M.T. (2006). Comparative study of growth performance of three strains of Nile tilapia,
Oreochromis niloticus, L. at two stocking densities. Aquacult. Res. 37:172-179.

Ruttner-Kolisko, A. (1971). Rotatorien als Indikatoren fur den hemismus von Binnensalzgewassern. Sber. Akad. Wiss. Math. -nat. Ki. Abt. I, 179: 283 - 298.

Timmons, M.B. and J.M. Ebeling (2007). Recirculating Aquaculture. NRAC Publ. No. 01- 007. Cayuga Aqua Ventures, Ithaca, NY, 975pp.

Tolussi C.E.; A.W.S. Hilsdorf ; D. Caneppele, and R.G. Moreira (2010). The effect of stocking density in physiological parameters and growth of the endangered teleost species piabanba, Brycon insignis (Steindachner, 1877). Aquaculture, 310:221-228.

Wallace, R. L. and T. W. Snell (1991). Rotifera. In Ecology and Classification of North American Freshwater Invertebrates: Academic Press, New York, USA 187 - 248. 